\title{
Language and Values:
}

\author{
Angkot and Bus Language Decoration in Ranah Minangkabau
}

\author{
David Reeve \\ Honorary Associate Professor, Humanities and Languages, Faculty of Arts and Social Sciences \\ University of New South Wales, Australia \\ d.reeve@unsw.edu
}

\begin{abstract}
Visitors to West Sumatra are immediately charmed and struck by the passenger vans (angkot) in the city of Padang and the buses of the province of West Sumatra - because of their extensive decorations, a combination of words and phrases together with symbols and pictures. These are mobile works of art and popular culture, a culture extended through booming loud music and the racing-car style of the drivers. As a language teacher I am always interested in collecting dynamic and dramatic words used in public spaces for teaching purposes, but as I collected a corpus of the language used, I came to see that there were sets of values embodied in the corpus, expressed by the phrases and the pictures. These values are radically different to the official values proclaimed by authorities. The values expressed in the angkot language, and to a milder degree on the buses, express a youth counter-culture within Minang society. But this creative, funny and dynamic popular culture is now under threat.
\end{abstract}

Keywords-languages; values; angkot; popular culture.

\section{INTRODUCTION}

The public transports of West Sumatra are extremely striking, creative and colourful, both its passenger vans called 'angkot' and its buses, which include the fast-disappearing city buses and the inter-city and inter-provincial buses. The angkot are the most striking, much more decorated and modified than in any other Indonesian city. They are covered with language, slogans and phrases in English, Indonesian and Minangkabau language, and occasionally with Arabic, and with pictures and symbols. These angkot have a large impact on visitors, who have called them 'eccentric', 'wow', 'trendy', though local Minangkabau are so used to them they rarely cause much comment. In fact, when they do attract comment it is usually critical and negative, from older people and from authorities. But to the outsider they seem a wonderfully creative use of local talent, modern, funny, dynamic and creative.

The buses are somewhat more conservative in decoration than the angkot, representing an older clientele and older drivers. The Padang city buses are closer to the angkot in their decorative style, with jazzy language and picture decorations but they seem in 2015 to be a rapidly dying art, with their rapid replacement by the Trans-Padang city buses and most of the older buses being sold off for scrap metal. The buses that go beyond the city, to nearer and farther reaches of West Sumatra, and to other provinces, are fortunately still highly decorated, with more actual scenes on their backs and sides than the city buses, moving paintings done by spray guns.

In this paper I will be examining the popular culture themes that are demonstrated by the language and the decorations on the angkot and the buses. What is soon evident is that there is a great yawning gap between these popular values and between what can be called the 'official' version of Minangkabau values. The language and pictorial decorations on the angkot particularly and on the buses show, for example, a yearning for speed, hi-tech, modernity, English language, masculinity and power.

The standard or official picture of Minangkabau culture looks quite naturally more to the past. This culture includes well-known and famous elements such as the distinctive Minangkabau styles of architecture, costume, food, dance and song, and above all its dynamic tension between older matrilineal custom or adat and the more recent patriarchal Islam.

The Minang are also famous for their linguistic aphorisms: they are highly addicted to proverbs (peribahasa) and most collections of proverbs are compiled by Minangkabau scholars. The Minangkabau are also noted for their addiction to pantun, a particular form of traditional Malay poetic wisdom, usually a four-line stanza with an 'a-b-a-b' rhyming scheme. Minangkabau people may be admired for their skill is using and creating pantun for special occasions, as for example family members at a wedding may engage in a 'pantun war' where they compete to toss the best and most appropriate pantun back and forth and at each other. So, this is a society in which verbal facility is highly valued, another useful context for the language on the public transport

Another special tradition is that of the rantau or journey outwards, where young men sojourn out of the Minangkabau region to live elsewhere, with the plan of eventually returning with new capital, financial and intellectual, new goods and new ideas to enrich Minangkabau society.

How-ever in the early part of this $21^{\text {st }}$ century there appear to be in fact two main discourses about Minangkabau values: the first is to praise Minang society for its famed openness, and the second, frequently heard, is that Minangkabau values are being eroded and are under attack from aggressive foreign values, particularly Western modernity, and that they need to be protected. The latter is a common theme amongst civil leaders, academics and teachers, cultural experts. 


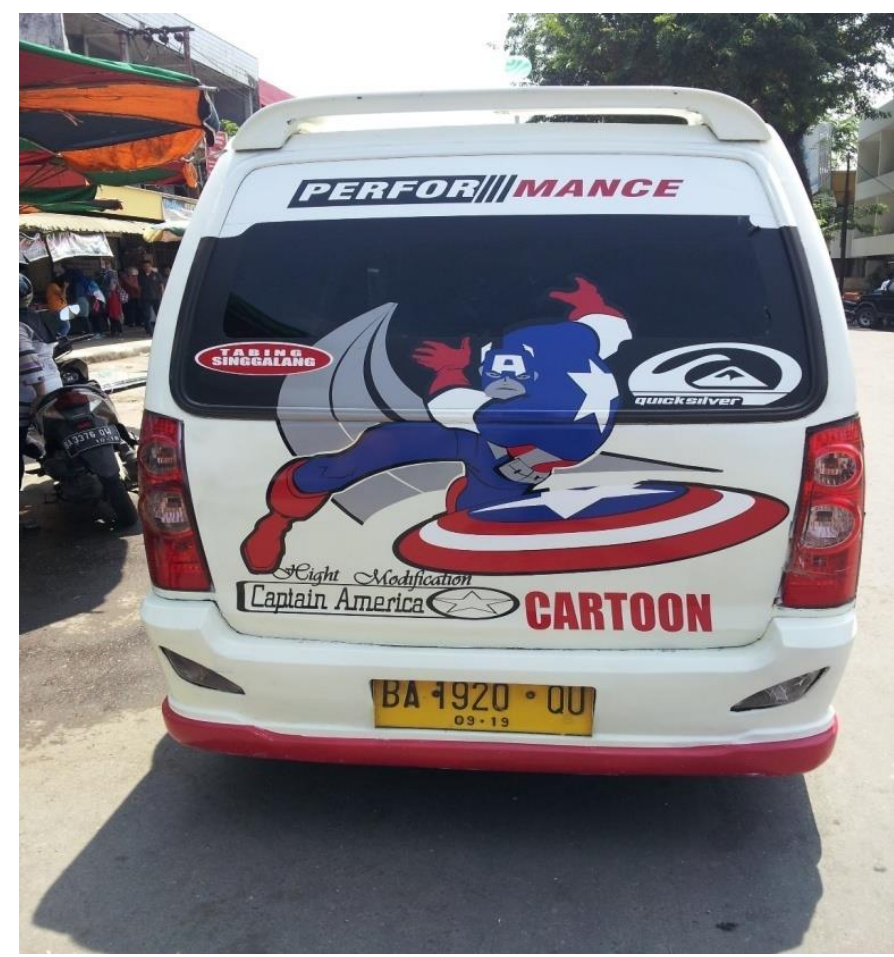

Fig. 1. Language decoration of an angkot to Tabing

In 2009 there were 2033 angkot, 199 city buses and 299 taxis. The figures vary slightly with different sources and include some 'wild' or unregistered angkot. The totals are more recently declining with the introduction of standardised Trans-Padang buses and with the greater use of private cars and motorbikes. I heard from several sources a figure of around 2000 angkot in Padang in 2014. Since 2017 the newest threat is from 'on-line' transport.

There are several cities in Indonesia where the angkot are a major and striking feature of the city-scape: Bogor, Medan, Malang, Batu, Kupang, Surabaya and Makassar for example. There are some similarities between the ways angkot in Makassar and Padang are decorated with symbols and language. But in Makassar most angkot are plain, some are slightly decorated, and a small number have several decorations. In Padang it is basically the reverse, in that a few angkot are plain, but most are highly decorated with much more complex patterns of decorations and language combinations.

\section{THE LANGUAGE DECORATIONS}

One of the key elements of the decoration is language, words and phrases.

This discussion is based on a collection of around 780 words, names, slogans and phrases. Broadly, there are about 450 English (and other foreign language), about 240 in Indonesian, formal and informal, and some 90 in Minangkabau. This means, again in broad terms, about nearly $60 \%$ English and other foreign, just over 30\% Indonesian, and just over $10 \%$ in Minangkabau language. In comparison, almost twice as many English/foreign as Indonesian, and about three times the number in Indonesian as in Minangkabau.

The first broad group here is foreign and mostly English words, which can be divided into ten broad categories as described below.

(1). Need for speed/powered engineering/Fast Cool Car: This identification with racing includes at least four important dimensions. First and second are a yearning for speed and a yearning for high technology. This is obvious from the list above, and from the ubiquity of racing styles and decorations. The third dimension is looking overseas. In Indonesia motor car racing is primarily a foreign and international but not particularly Indonesian sport particularly compared to Indonesian motorbike racing which is highly local. This international dimension is also shown by this collection of words being in English. The fourth dimension is masculinity. Motorcar racing is a very masculine field in Indonesia, as is driving an angkot in Padang. Racing stars in Indonesia are invariably men.

These elements are underlined by some of the other smaller categories of words and phrases from the angkot. For example, along with the 'racing' category, there is another sports grouping (2), of tough and strong sports associations; also (3) a hi-tech group, with words from modern technology. The hi-tech dimension is strengthened by (4) website names and addresses, mostly in English, for example : $w w w . x \_p l o d$, autorace.com, www.putri.com ... and many more. Another set gives the names of the groups of drivers, frequently using the terms family, community, or club, for example: D.A.C./Dimaz Auto Community; $x$-plod padank community; Lotus The Real Community; to-co new family; Mata Cantik Auto Community; Blitz Car Auto Club; Cherita Big Family.

The next largest group (5) of words is of words and phrases conveying superlatives, strength, status, power and impact, such as: Absolutely, Best, Excellent, Hot, King, Kingdom, Never, Perfect, top, Viper. One of them is 'Power' and this is exactly right; these are 'power words'. A third major category (6), though smaller than the first two, is of powerful occupations, powerful men, military themes and executive class, Samurai/Executive. One of these is 'Commando', and it is my experience that, across the whole archipelago, this is the singular most popular word to decorate Indonesian public transport. But for the angkot Padang it is more than a word; it is a major theme in angkot decoration, and highly consonant with the above-mentioned themes of modernity, masculinity and power.

Masculinity themes (7) are also seen in the frequent occurrences of references to boys, and rarely to girls, except perhaps 'Tomboy'. Another theme or grouping (8) suggests a strong orientation towards Western urban and popular culture, with one part of this grouping referring directly to American cities or cities in general, very strongly complementing the Western popular culture on the angkot decorations, while other words point to other aspects of popular culture, brands, phrases, music, and even Gangstrarasta, and the Japanese cartoon Keroppi but within an English language phrase. 
One further theme (9) extends the masculinity grouping with a set of words suggesting romantic and sexual feelings towards women, rather like an Indonesian film or television sit-com, either romantic yearnings - forever in love - or rather lusty thoughts of men as actors - Mafia Campus, Mugen Auto Playboys -and women as sexual objects - Golden Boy/Play Girl. This is underlined by the depictions of women in angkot pictures. A small but significant group emphasises attachment to family. The final group (10) to be discussed is a group of words suggesting a tough and individualistic attitude, and attitude of indifference and rejection of society. That this grouping is important is underlined by the number of cartoon decorations on the angkot indicating anti-social behaviour.

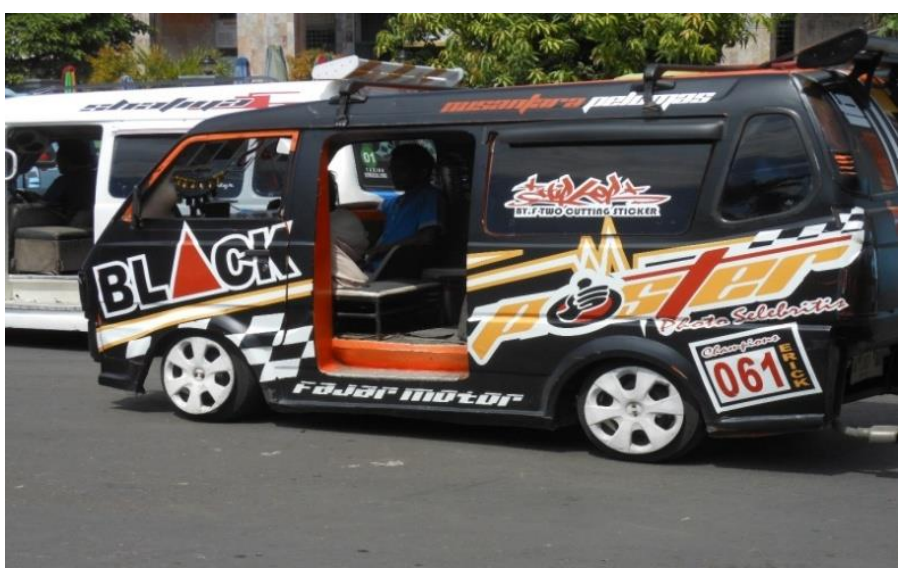

Fig. 2. Decoration of Angkot Lubuk Buaya

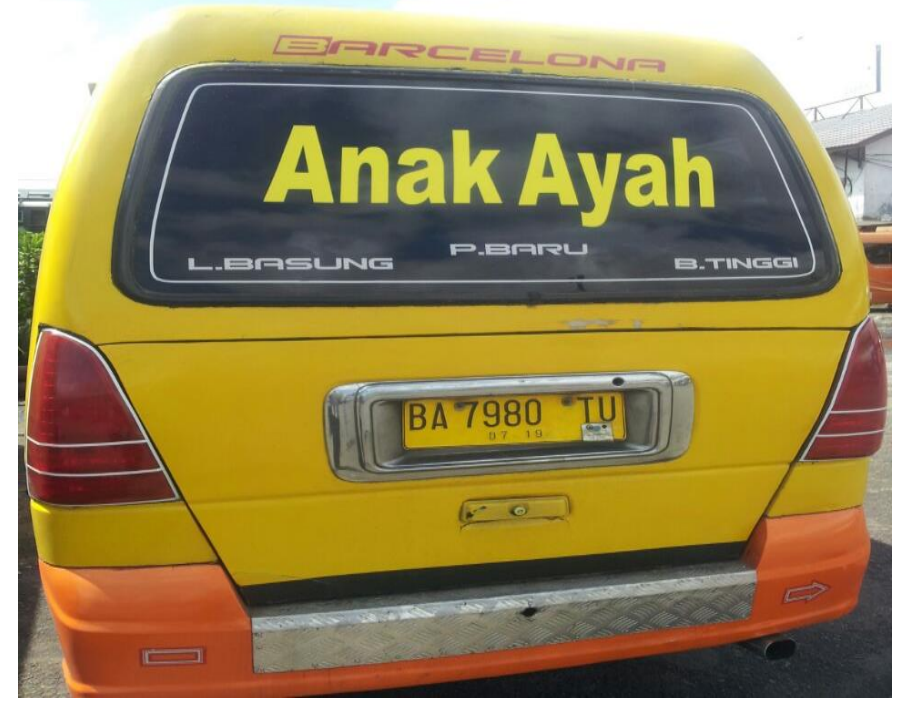

Fig. 3. A microbus decoration

The corpus of Indonesian words and phrases produces some different emphases. There are only a few words to do with speed/racing/sport (for example sportivo, Ratu Speed; Timbul Sport), such as are so striking in the foreign language corpus, but this indicates how overseas-looking the very important speed/racing grouping is. In the Indonesian words and phrases collection, the theme of family is stronger than in the English collection, suggesting its greater importance nearer to home. This grouping includes the names of family members, as are very often used on angkot decorations, and phrases like 'mother's prayers', 'father's prayers'.

A second group is made up of words and phrases suggesting status and/or strength, for example: Adipati; Baret; Begundal; Bertabur; Biawak; Bintang; bintang Bullex's; Devisa; Dewi Fortuna Selatan; Dewa; Duta Paris; Gempar; Marlboro; Mahkota; Makmur; Maestro; Merdeka; Mobil Para Bintang; Nirwana.

The romantic/sexual world of the young men and of young men's culture was already seen in the English language groupings, and is a larger group in Indonesian, with references to young stars, spoiled girls, passion, night transport and sweet memories, and to popular cartoons and films such as Bobo Boi, a Malaysian animation and the Indonesian film Laskar Pelangi. To these can be added some smart, trendy and humorous phrases, suggesting trendiness.

Register: Informal: Gaul trend /Lagi Ngetop: However the largest grouping of Indonesian words is the group that falls into the category of informal or 'trendy' language, bahasa gaul, usually associated with youth - though not only used by them - and frequently the target of criticism by the older generation. The selection below shows many ways of being classified as bahasa gaul.

ABG; ABG tua; Abis; babe; Begundal; Bocah Elite; brandal elite; Bule; bonekagaul; Cabe-Cabean; Centil; ceweknalpot/cepot; Chayank Papa; C-lebritis ABG; Cowok Broken; DuSex/Dua Saudara Express; dengerin music c.o.m.m.; Emang Situ OK ...??; gaul!; Gaul trend; genit; Gesit; Gile; Gombal; Hai! Godain Kita Dong; Guri-Guri yoi; Jablai; jangan neko-neko; Jomblo; Kamu; Lagi Ngetop; mr. gelek; Nggak Level; ngerayap; Ngeyel; nge-fly; Nggak Level; nyokap gue; O .. asyik; Oplosan; Sexx Aku/Lu $\mathrm{Mu}$; Raja Dayak Gaul; Rasta Mania; Tante sexy; Toean Moeda; Two one moeda; trans-gaul; Tulalit; ya ..ya ..iayalah; Virgin2 Caci Cici; [WB] Warga Biasa; WB/ Warga Bravo Wardana.

The phrases may refer directly to 'gaul' as in boneka gaul, gaul! and Gaul trend, and Raja Dayak gaul (trendy King of the Dayaks), or trans-gaul in imitation of the 'Trans-Padang' city bus line. Or the words may have become 'gaul' from some spelling changes systematically applied to existing formal vocabulary. There may be borrowings from other established patterns of gaul language, such as bahasa prokem which became popular in the 1980s, apparently derived from the semi-secret code languages of criminals (preman), passed to Jakarta youth via drug-dealings.

There are other highly frequently occurring informal words that give a particular emotional intensity to an existing phrase, particularly dong, deh and sih, giving a range of emotional feelings to the phrases, as in the angkot phrase above Godain Kita Dong, or 'tempt me please'/'have a go at me please', which uses the 'in' ending and 'dong'. Gaul terms may be made up with humorous acronyms and initials, such as ABG, standing for 'big kids, grown up but still immature', or 'anakbarugede', in which the full form of the phrases uses another form of borrowing common in Bahasa gaul, in which low Javanese words are imported into informal Indonesian, with in this case gede being low Javanese for 'big'. In the list above ABG appears by itself but also in 'ABG tua' - 'old big 
kids' - and 'C-lebritis ABG', meaning 'teen celebrities.' Also in DuSex/Dua Saudara Express, the longer phrase is made into the acronym DuSex, which become 'nakal' or 'naughty' by alluding to sex.

There is a small number of Arabic/religious phrases.

The Minangkabau words and phrases, according to the informants who translated them, have a strong feel of street talk and informal language, which they call 'gehol', a local term for gaul language. There are some straightforward formal phrases, but several aspects of gaul culture, as with the aberrant spellings: Padank for Padang, rank for rang/orang/person, and other similar usages.'

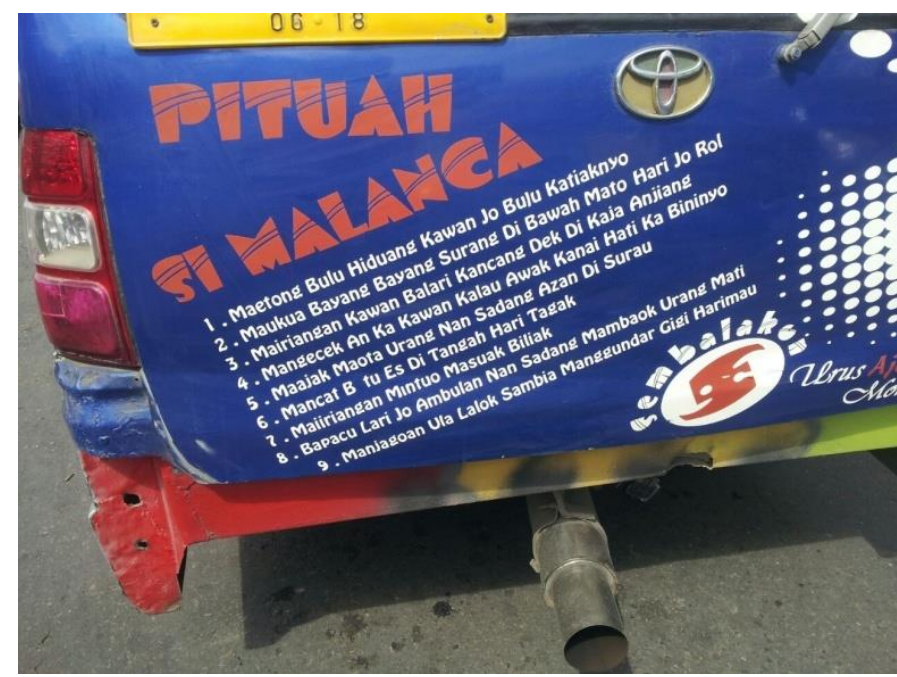

Fig. 4. Pituah "Advice" in an angkot language decoration

\section{COMMENTARY ON THE LANGUAGE AND PICTURE DECORATIONS}

In other areas of Indonesia, most angkot have only a little decoration or none, and the highly decorated angkot are the exception. In Padang it is the reverse. In Padang the great majority is highly decorated with language and picture decorations. It is a similar case with buses. Around Yogyakarta and in Bali a minority is decorated; in West Sumatra it is the majority.

Why is it that the angkot and buses are so decorated in West Sumatra? It seems to me that the answer is related to two traditions in West Sumatra, one of the high decoration of transport seen with bendi traditional horse carts, and the other of a society marked for the high value placed on clever language use, as traditionally with pantun and proverbs. This is not to argue a direct, causal relationship and to say that because these traditions exist therefore there is a high degree of decoration. It is rather to point to the nature of the public transport industry in West Sumatra, where there are many small owners in a highly competitive business environment.

In the early 1990s these owners were competing for market share and trying different strategies. One owner experimented with the combination of music and language/pictures decoration, and the combination worked. It was then widely imitated, creating a tradition of bus and angkot decoration that has now lasted for around a quarter of a century. The successful angkot and buses used a modern version of two older traditions. And the values they expressed had a great appeal to their customers, particularly a youth clientele for the angkot, and a rather older clientele with the buses.

The differences of emphasis are evident in the broad patterns of angkot and bus language, in the collection of over one thousand words and phrases. Once again, because of the ever-changing nature of the corpus of words and phrases, it is important to identify broad but durable trends. The first to notice is the continuities but differences in the patterns of use of languages in decorations on angkot and bus, with three consistent main categories:

TABLE I. LANGUAGE CATEGORY IN DECORATION ON ANGKOT

\begin{tabular}{|l|c|c|}
\hline \multicolumn{1}{|c|}{ Languages } & Angkot Language & Bus language \\
\hline Foreign/English & $59 \%$ & $40 \%$ \\
\hline Indonesian & $30 \%$ & $49 \%$ \\
\hline Minangkabau & $11 \%$ & $12 \%$ \\
\hline
\end{tabular}

The quantity of foreign language decorations, the large majority English with a few Japanese, is very striking with angkot, just under $60 \%$, underscoring the yearning for an overseas modernity. The foreign language use is still quite large as a total and a percentage with the buses, but with the leading roles reversed; with the buses the largest language component is Indonesian, though at just under $50 \%$ not as striking as the nearly $60 \%$ foreign with the angkot. In both cases 'Indonesian-ness' is important, less so with the angkot, more so with the buses.

The Minangkabau element is stable across the two samples at a bit more than $10 \%$. It is fascinating that Minangkabau public transport, in the Minangkabau region, with Minangkabau owners and drivers, use only around $12 \%$ Minangkabau language words and phrases as decorations on their vehicles, and almost $90 \%$ of the language decorations are in Indonesian and foreign languages.

The table above indicates a consistent use of three sorts of language for the decoration, with a greater foreign-ness for the angkot and a greater Indonesian-ness for the buses, and a consistent minor but significant role for Minangkabau language. The Minangkabau elements are an important if more minor element in the mix of values that make up the popular values expressed in the decorations. They are important for the synthesis, for the gaulcreation made out of a blending of several elements. Some of the Minangkabau language is serious, referring to family or to Minangkabau places. But informants on the Minangkabau language collection spoke several times of 'gehol', 'street talk', and 'youth talk', and of aberrant spellings and uses.

Sometimes the Minangkabau language is in large fonts but often it is in small fonts, off to the side or low down on the body of the vehicles, offering a sardonic or cheeky comment or coda, anchoring the other languages in a Minangkabau reality.

As we have seen, there is a high correlation between the English language of the angkot and one of the major themes of the styling of the vehicles and their pictorial decoration, and 
that is the theme of racing, with its constituent elements of speed, modernity, high technology, overseas orientation and masculinity. The racing and speed theme is also strong on the buses, not so much through the language, but by the number of buses that have pictures of racing cars and water-skis, and powerful vehicles such as planes, boats and rockets. The overseas orientation is strong in angkot and the buses through the language decorations and the pictures referring to western cities and culture, and also particularly to a wide range of popular culture figures from western and Japanese cartoons.

There is a consistent theme of 'power' words, associated with high status, high impact, superlatives, praised attributes, and, particularly with the angkot, with tough masculine roles like commando and samurai. The desire to be strong, assertive and of high status goes along with a teen romance and desire approach to women, romantic yearnings and the fantasy of the golden boy with the "king ladies". These various themes complement the gaul effect of the language and of the overall look of the angkot and many of the buses, with the gaul effect coming from some of the phrases themselves, from the mixing of languages on the same vehicle, and from the mixing of the language with the picture decorations.

There is a consistent theme across angkot and buses, and across languages, of 'family', both the real family of parents, brothers and sisters and children, and for the angkot especially, the particular small family or community or group to which the drivers belong. This is a more conservative theme than the youth culture elements already outlined and suggests the complexity of the values endorsed through the decorations.

One reaction at seeing this vivid display on the streets of Padang and the main roads of West Sumatra is to think that there is something "very Minangkabau" about these syntheses and mixes of languages and images. It is a society that has a rich tradition of seeking out the new from the outside and reintegrating it back at home. So in this way these syntheses of outside influences onto a local base might be seen as quintessentially Minang.

But the central problem with this feeling is that angkot have a bad name in Minang society, and are generally seen as undesirable and transgressive, in established adult mainstream opinion.

What is not said directly, but I think recognized, is that the package of values expressed in the angkot decoration runs counter to official Minangkabau values. Not only is the behaviour transgressive, but so are the values. As one academic said: 'Yes, they are creative, but creative in the wrong way.' So although there may seem to be something very Minangkabau about the angkot to an outsider, they are rejected as transgressive by mainstream adult opinion, seen as a problem rather than something to be celebrated. Within Minangkabau society the values expressed particularly by the angkot but also across a large section of the buses amount to a counter-culture, the values of which amount to a large extent to a criticism and rejection of mainstream values, and a longing for a quite different sort modern future; but for me a set of values presented in especially lively, dynamic, funny and creative ways. It is a shame this popular culture is now under increasing threat.

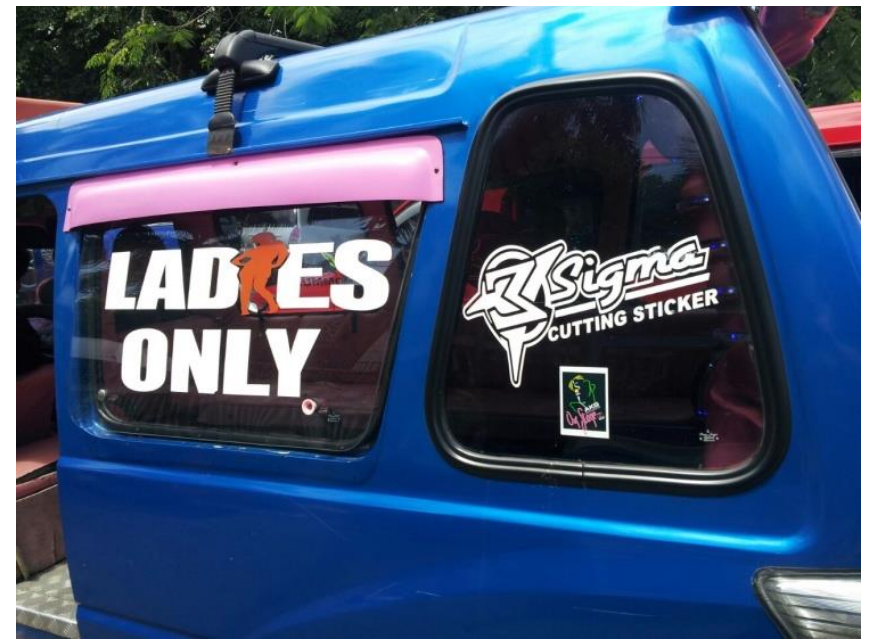

Fig. 5. "Ladies only" language decoration

This paper is based on sections of David Reeve, Angkot dan Bus Minangkabau. Budaya pop dan nilai-nilai budaya pop/Popular culture and popular values, Komunitas Bambu, Jakarta, March 2017.

\section{References}

Basthomi, Y. (2006). 'Truck Graffiti: The Rhetoric of Emulation' in Edda Weigand (ed), Dialogue Analysis XI, iada.on.line.series, 1(09), 217-228.

Chambert Loir, H. \& Rahardja, P. (1990). Kamus bahasa prokem. Jakarta: Pustaka Utama Grafiti.

Crossby, A. (n.d.). Padang Transport, retrieved: https://www. flickr.com/phptos/alimander/1368991622.

Fikrilla, Z. (2010). Simbol angkot dan maknanya. thesis. Sosiologi-Antropologi. Padang: Fakultas Ilmu-ilmu Sosial, Universitas Negeri Padang.

Jones, T. (2008). Bomb the base in the bus: Public transport as intersections of a local popular culture in Padang, Indonesia'. Continuum: Journal of Media \& Cultural Studies, 22(1), 127-139; http://www.tanffonline.com/ doi/pdf/10.1080/10304310701729910, accessed September 09, 2014.

Parker, L. (2014). The moral panic about the socialising of young people in Minangkabau. Jurnal Wacana, 15(1), $19-40$.

Putra, R. (2013). Sopir dan angkot gaul di Kota Padang. Thesis, Padang: Fakultas Ilmu-ilmu Sosial, Universitas Negeri Padang.

Sahertian, D. (1999). Kamus bahasa gaul. Jakarta: Pustaka Sinar Harapan. 